\title{
Assessing vulnerability of low-income communities to indoor air pollution in South Africa: towards the development of a vulnerability index
}

\author{
M. Binedell \\ Division of Water, Environment and Forestry Technology, \\ CSIR, South Africa
}

\begin{abstract}
Health Risk Assessment (HRA) is a valuable tool for determining the potential human health risk associated with environmental exposures to hazards. HRAs are, however, limited in that they do not allow an assessment of other factors which may render people more vulnerable. Low-income (and often marginalised) communities are subjected to multiple environmental exposures and often lack the coping mechanisms that enable them to resist, cope with and manage their exposure to hazards. This paper presents the components of a proposed vulnerability index that could be used to assess levels of vulnerability of lowincome communities that are exposed to indoor air pollution. A number of social, biophysical and service-related factors which are particularly relevant to the South African context have been considered and are discussed further. Keywords: vulnerability, household risk factors, indoor air pollution.
\end{abstract}

\section{Introduction}

Traditional health risk assessments aim to determine the probability and magnitude of risks to human health from exposure to a particular hazard. These assessments consider some of the characteristics of an exposed population, such as age and length of exposure, and include these into the assessment of risks. However, there are a number of other physical, social, economic and built environment factors which may influence the magnitude of adverse health effects 
(particularly for low-income households) that are not accounted for in traditional risk assessments.

The purpose of this study was to develop an index for assessing vulnerability of low-income households to indoor air pollution. The index was designed to incorporate vulnerability risk factors which not only heighten one's exposure to indoor air pollutants but also contribute to the household's ability to cope with indoor air pollution and the effects thereof. This paper discusses the components of the vulnerability index and explains their relevance to the South African context.

\section{Background}

The study area of Cato Crest is an informal settlement located a few kilometres from the central business district of the city of Durban, located on the eastern seaboard of South Africa. It is one of the most densely populated informal settlements in Durban and consists of an informal network of dirt roads and pathways amongst a number of self-constructed dwellings. Service provision is lacking and houses are poorly constructed. Most households share pit latrines and water pipes [1]. Overcrowding, a high crime rate, unemployment and a high prevalence of HIV/AIDS are some of the key problems facing this community. In addition, the lack of electricity in the area necessitates the use of kerosene (paraffin) which has been linked to a number of health effects in exposed individuals [2]. A health risk assessment conducted in the community demonstrated high risks to human health from kerosene combustion, used mainly for cooking purposes [3].

\section{Vulnerability and risk}

Wisner [4] (in his study of Tokyo's urban poor) called for the inclusion of social variables when assessing vulnerability of urban groups. He states: "socioeconomic status, occupation and nationality have a marked effect on access to information and services as well as on resources available to people for selfprotection and recovery. Certain status, occupation and nationality groups suffer increased vulnerability because their capacity to cope and to recover has been diminished" [4, p27]. He further states that there is evidence to show that people with certain social characteristics are more likely than others to be affected by lack of resources and the lack of access to these resources.

Within the field of disaster management, much has been done to develop, test and validate tools, methodologies and other instruments for factoring issues related to social equity (including gender analysis) into risk management at the local level $[5,6]$. According to the International Strategy for Disaster Reduction (ISDR) some phases in risk assessment are weak and therefore people's strengths and abilities, their susceptibilities, socio-economic status and gender should be considered [6]. They suggest that people's risk perceptions and the socioeconomic and environmental context within which they live should be incorporated, and are essential in the identification of risk scenarios [6]. 
In the ISDR disaster management assessment, two elements are essential in the formulation of risk: the probability of occurrence for a given threat - the HAZARD; and the degree of susceptibility of the element (community) exposed to that source - VULNERABILITY. Coupled with this is the growing interest in the positive capacities of people to cope, withstand and recover from the impact of a hazard.

The development of comprehensive risk assessments thus far focuses on conventional hazardous phenomena such as windstorms, earthquakes and floods; but the approach can also be applied to assess the risk and vulnerability to human-induced environmental hazards of indoor air pollution.

It is therefore imperative that risk assessments should incorporate dimensions of physical, social, economic and ecological vulnerability. Although the complexity of the environmental change process makes assessing and measuring human vulnerability highly speculative [7], an attempt to 'factor in' vulnerability into the risk assessment equation provides an assessment which may be more socially acceptable. The inclusion of vulnerability and capacity assessment in risk assessments is a move forward to better understanding the full risk to human health and well-being.

\section{A vulnerability index for indoor air pollution}

\subsection{Methodology}

The methodology used to derive variables of vulnerability in this study was systematic and consisted of a series of three filters. They were: A literature survey of the concepts of urban poverty and vulnerability; primary vulnerability data collected from households in Cato Crest; and the development of vulnerability indicators. The variables (or indicators) are specifically relevant to the South African context as well as to an informal settlement community who is exposed to an environmental factor such as indoor air pollution [8].

\subsection{Components of the vulnerability index}

The indicators and measures which were derived through the above approach were grouped within six broad themes. These themes, indicators and measures are shown in Table 1.

The section which follows provides a description of each of the themes and indicators which form part of the vulnerability index. It should be noted that this index has been specifically developed for the South African context and more specifically for the assessment of vulnerability of low-income, informal communities to indoor air pollution. Scoring and weighting of each variable in the index and the possible aggregation of variables into a single vulnerability score, is the subject of ongoing research. It is therefore not discussed further in this paper. 
Table 1: Indicators and measures as components of a vulnerability index [8].

\begin{tabular}{|c|c|c|c|}
\hline & THEME & INDICATOR & $\begin{array}{l}\text { MEASURES (Environmental, } \\
\text { social \& economic) }\end{array}$ \\
\hline \multirow[t]{2}{*}{1} & \multirow[t]{2}{*}{ Demographics } & Gender & $\begin{array}{l}\text { Ratio of males to females per } \\
\text { household } \\
\text { Gender of household head } \\
\text { Percentage of males older than } 18 \mathrm{yrs}\end{array}$ \\
\hline & & Age & $\begin{array}{l}\text { Age of household head } \\
\text { Average age of household }\end{array}$ \\
\hline \multirow[t]{4}{*}{2} & \multirow[t]{4}{*}{ Livelihoods } & Unemployment rate & $\begin{array}{l}\text { Percentage unemployed of } \\
\text { employable age }(>18 \mathrm{yrs})\end{array}$ \\
\hline & & $\begin{array}{l}\text { Income distribution } \\
\text { and dependency }\end{array}$ & $\begin{array}{l}\text { Monthly household income } \\
\text { Per capita income } \\
\text { Percentage of household contributing } \\
\quad \text { to household income }\end{array}$ \\
\hline & & Dependency on care & $\begin{array}{l}\text { Ratio of adults to dependents (Ratio } \\
\text { of children }>15 \mathrm{yrs}:<15 \mathrm{yrs} \text { ) } \\
\text { Number children under } 15 \mathrm{yrs} \text { who do } \\
\text { not go to school }\end{array}$ \\
\hline & & Levels of education & $\begin{array}{l}\text { Percentage of household achieving } \\
\text { grade } 10 \text { (of potential age) }\end{array}$ \\
\hline \multirow[t]{3}{*}{3} & \multirow[t]{3}{*}{$\begin{array}{l}\text { Physical } \\
\text { exposures }\end{array}$} & Overcrowding & $\begin{array}{l}\text { Number of people per square metre } \\
\text { Number people per household }\end{array}$ \\
\hline & & Air pollution & $\begin{array}{l}\text { Percentage of household sleeping in } \\
\text { cooking area } \\
\text { Percentage windows which open }\end{array}$ \\
\hline & & Waste & $\begin{array}{l}\text { Frequency of removal } \\
\text { Cost of service }\end{array}$ \\
\hline 4 & Externalities & Building materials & $\begin{array}{l}\text { Presence of damp } \\
\text { Type of materials }\end{array}$ \\
\hline \multirow[t]{3}{*}{5} & \multirow[t]{3}{*}{ Services } & $\begin{array}{l}\text { Access to water } \\
\text { supply }\end{array}$ & $\begin{array}{l}\text { Number litres accessed per day } \\
\text { Proximity to source } \\
\text { Reliability } \\
\text { Cost of service }\end{array}$ \\
\hline & & Quality of water & Potability \\
\hline & & Sanitation services & $\begin{array}{l}\text { Type of toilet } \\
\text { Private or shared facilities } \\
\text { Odour problems } \\
\text { Cost of service }\end{array}$ \\
\hline \multirow[t]{2}{*}{6} & \multirow[t]{2}{*}{ General health } & Food and nutrition & $\begin{array}{l}\text { Percentage of nutritional problems } \\
\text { recorded at clinic }\end{array}$ \\
\hline & & Other diseases & $\begin{array}{l}\text { Number of household members with } \\
\text { pre-existing respiratory problems } \\
\text { Prevalence of HIV/AIDS in the } \\
\text { community/area } \\
\text { Prevalence of diarrhoeal diseases in } \\
\text { the community } \\
\text { Prevalence of Tuberculosis in the } \\
\text { community/area }\end{array}$ \\
\hline
\end{tabular}




\section{Vulnerability themes and indicators}

\subsection{Demographics}

Demographic indicators of gender and age can reflect vulnerability in lowincome households as these variables influence a household's access to resources and health care. Social exclusion and vulnerability in South Africa follow gender and racial lines, with certain groups of the population (such as rural people, women and the youth) more vulnerable to social exclusion than others [9].

Rakodi et al [10, p156] found that "women household heads were thought to be vulnerable because they have had poorer access to education and have as a result lower literacy rates. They own limited productive assets, especially land and have limited access to credit than men. They tend to be ignorant of their rights and thus exploited and discriminated against in economic activities".

Rakodi et al [10] goes on to state that young people in low income groups have been described as "helpless, frustrated and dangerous" due to the fact that they lack practical training necessary to secure employment. The age profile of households provides a measure of the potential for the household to access employment and therefore sufficient income to sustain their livelihoods. Households with many young children are more dependent on others for care and may limit the caregiver from involvement in economic activities which would generate income.

The presence of adult males in the household may contribute to a sense of safety. Conversely, the absence of males, especially in areas where there is civil unrest or violence, may contribute to a household's insecurity. This may affect their sense of well-being and contribute to their anxiety and mental stress. In addition, it could worsen indoor air pollution because people keep their windows closed, thereby limiting ventilation.

Gender and age are visible issues in Cato Crest, with $42 \%$ of the surveyed households run by female heads. Female-headed households also contained other siblings and a number of dependent children, whilst some male headed households had fewer dependents and higher household income. In Cato Crest the mean age of households is 28 years of age with $15 \%$ of households run by pensioners (people over 60 years of age). Another important gender-related issue is the high prevalence of HIV/AIDS amongst females aged 15 to 35 years, indicating that females in this age group are more vulnerable to infection [11].

\subsection{Livelihoods}

Unemployment, income distribution, dependency on care and education are the four indicators used in this study to determine livelihood status of households. According to the literature $[10,12,13,14]$, the rate of unemployment is an important determinant of urban poverty and vulnerability. Unemployment and lack of income can also prevent a household from accessing the required food and nutrition for maintaining a healthy body and can contribute to the more rapid progression from HIV infection to AIDS [15]. 
Income distribution and economic dependency are regarded as the highest measures of poverty. The extent of income poverty in Cato Crest is high, with only half the number of households maintaining a per-capita income above the poverty line [1]. Unemployment and the resulting lack of income can forcibly increase levels of exposure to pollutants through the use of cheaper and 'dirtier' fuels. Increased exposure can result from the use of non-electrified energy sources such as kerosene, as well as through extended exposure times in the home as opposed to the work environment where indoor air pollution may not be as great a hazard.

The issue around dependency on care in this study arose through the identification of a number of young children in the household who were not at school. While questions on child care were not asked in this study, it is expected that these children were dependent on another family member or caregiver to care for them. This creates a large burden on the caregiver who could be otherwise free to pursue economic activities.

According to the World Health Organization [16], lack of education limits the ability of the poor to identify and take appropriate action to improve their health and secure their basic needs. Education at the household level gives an indication of the potential for individuals to enter the formal employment sector based on a recognised level of education.

\subsection{Physical exposures}

Overcrowding, air pollution and waste disposal are included as indicators of vulnerability related to physical exposure. Overcrowding is responsible for unsanitary conditions and can allow for the prolific spread of disease. Both poor ventilation and inadequate sized housing aids the transmission of diseases such as tuberculosis, influenza and meningitis. Crowding has been noted as a direct health factor in a number of health studies [17]. Risks of household accidents may increase and the burden to safeguard children from fires and stoves becomes greater. Overcrowding has also been recognised as having an influence on quality of life [2].

Crowding was one of the first issues to be identified in the household survey in Cato Crest. Eighteen percent of households consisted of more than 5 members per house, with the average household size being 3.69 members [1]. This is high considering that most houses in Cato Crest and many other informal settlements consist of only one room

Air pollution is a common environmental hazard affecting people living in unserviced settlements. Apart from not having the option of electrification as an energy source, informal households lack the income to pay for electrical appliances and therefore rely on cheaper methods for cooking and heating which use 'dirtier' fuels such as kerosene or coal. Poorly designed stoves and smoky fuels further exacerbate the problem. One of the dangerous pollutants which arise from kerosene combustion, nitrogen dioxide, has been shown to be associated with increased susceptibility to respiratory infection [18].

Unsanitary conditions caused by uncollected waste encourage the proliferation of disease. Burning and dumping problems in informal settlements 
seem to be related to the lack of adequate waste removal services [2]. People living in unserviced settlements are also exposed to disease-carrying vectors such as rats, mice and flies which proliferate in uncollected waste and refuse. These conditions may contribute to a greater burden of disease and a reduced ability of the body to recover from these diseases, particularly in immunocompromised individuals.

\subsection{Externalities}

Low-income communities are exposed to a variety of hazards which arise from both the type of building structure they live in as well as the location and condition of the house. Building materials contribute to water leakages and the development of mould leading to poor respiratory health and allergic responses. $[2,17]$. Lack of windows (or small windows) leads to poor ventilation which prevents harmful pollutants from being dispersed.

According to the United Nations [19], poor living conditions are associated with poverty, homelessness, poor health, social exclusion, family instability and insecurity, violence, environmental degradation, and increased vulnerability to disasters.

Apart from household building materials, informal settlements are often found on marginalised land next to hazardous waste sites, industrial areas or quarries. Lack of facilities associated with these informal settlements compound the risk to environmental hazards and prevent the community from gaining access to knowledge (through the provision of libraries and information centres).

\subsection{Services}

Lack of services in low-income communities can contribute to environmental degradation and exposure of individuals to a variety of health hazards. Access to water, quality of water and sanitation services has been considered.

In Cato Crest, no households collect water from rivers or streams as they have access to piped water, mainly to a shared tap or water carrier. Contamination of water supplies is a particular problem in areas where sanitation facilities, waste disposal services and wastewater removal systems are absent. Water contaminated by sewage may expose users to a wide range of diseases such as cholera or typhoid, with infants and children being particularly vulnerable. Apart from the risk of infectious water-borne diseases, standing water around standpipes can allow proliferation of mosquitoes, a vector of the malaria parasite.

Access to adequate, reliable and safe sanitation has been used as a good universal indicator of human development [19] and is one of the eight elements of primary health care. It is therefore a significant indicator of potential risk of disease. In Cato Crest, 91\% of households have access to pit latrines (half of whom share with neighbours) amounting to an average of 8 users per latrine.

\subsection{General health}

Food and nutritional deficiencies, incidence of respiratory disease, prevalence of HIV/AIDS and other communicable diseases are important health issues facing 
low-income communities. Moser [20] includes an individual's access to adequate nutrients and healthcare as one of the most important determinants of well-being.

Low-income communities often lack the resources to purchase or grow the necessary spectrum of foods which will provide the household with a wellbalanced diet. Nutritional deficiencies and the inadequate intake of certain micronutrients can lead to malnutrition and the lowering of resistance to certain diseases [21]. Studies have shown that people with a vitamin $\mathrm{C}$ deficiency may be more susceptible to impaired air quality, as vitamin $\mathrm{C}$ inhibits the oxidation reactions of nitrogen dioxide $\left(\mathrm{NO}_{2}\right)$ in the body [22]. Long-term malnutrition has also been shown to increase susceptibility of the developmental effects of toluene - a pollutant emitted during kerosene combustion [22].

People with pre-existing chronic respiratory problems are more susceptible to exposure to $\mathrm{NO}_{2}$ and other respiratory toxicants. Studies have shown that $\mathrm{NO}_{2}$ can increase susceptibility to respiratory infection making children and infants in particular, more susceptible to viral and bacterial attack through inhalation, causing an increased incidence of diseases [18]. For example, tuberculosis impairs the ability of the lung to eliminate particulates and the air borne toxicants which bind to particulate surfaces. This condition therefore increases a tuberculosis sufferer's susceptibility to lower levels of air pollution [21].

Individuals with pre-existing diseases are more susceptible to additional hazards. Furthermore, vulnerable communities often do not have access to vaccines and anti-bacterial/viral drugs which makes them more vulnerable to infection, and increases the length of recovery from an existing illness. In this study, the prevalence of diarrhoeal diseases and tuberculosis has been chosen to represent the potential pressure that may exist in households exposed to the additional hazard of indoor air pollution.

Diarrhoea is a symptom of infection from a variety of water-borne diseases caused by a number of micro organisms affecting the intestinal tract. The incidence of diarrhoea has been associated with unserviced households which are reliant on untreated water sources.

Tuberculosis (TB) is the most frequently notified disease in South Africa and is rising with the proliferation of HIV/AIDS [23]. A strong correlation exists between the presence of HIV/AIDS and the presence of TB in individuals. Distribution of TB in South Africa indicates strong geographical and racial disparities being influenced strongly by socio-economic status [24].

The burden of HIV/AIDS is heavy on low-income households. It is recognized as a driver of vulnerability (in that it affects a person's immune defence mechanisms) as well as a consequence of vulnerability (in that HIV infection and the onset of AIDS are perpetuated by a variety of physical, social and economic determinants of low-income livelihoods) [15]. The onset of AIDS in an HIV-positive individual can be accelerated by exposure to high levels of nitrogen dioxide arising from combustion of fuels such as kerosene [18]. Socioeconomic impacts of HIV/AIDS include lowered life expectancy, dependency on care for the sick, dependency on care for infants and children, and an increased social stigma associated with HIV status. In Cato Crest, HIV prevalence has 
increased from $41.4 \%$ in 1999 to $45.3 \%$ in 2000 with the highest prevalence in the 20 to 29 year age group [11].

\section{Summary}

The purpose of this study was to generate a vulnerability index that can be used to assess levels of vulnerability of low-income communities exposed to indoor air pollution. The variables in the index have been selected based on available literature of the direct or indirect influence of that variable on heightening vulnerability or provision of coping mechanisms. Local issues were included, ensuring relevance to the South African informal settlement context.

Several important points need to be made regarding the index. Firstly, the index may be used to measure vulnerability of a community or household at a particular point in time as people's vulnerability may change over time. Secondly, selection of many of the variables relies on subjective judgement and many assumptions have been made. This paper discusses the components of the vulnerability index and explains their relevance to the South African context. Further work is required on the weighting and possible scoring of each vulnerability factor in order to derive a single score of vulnerability. This would facilitate the integration of traditional health risk assessment results with a vulnerability assessment - ensuring that 'true risk' is assessed.

\section{Acknowledgements}

The author wishes to thank Elizabeth Muller and Mamopeli Matooane for their contributions to this paper and to the community of Cato Crest.

\section{References}

[1] Vermaak, K., Gumede, S., Dallimore, A. and Stewart, R. Cato Manor environmental study, Report no. P8-2, CSIR, Durban, 2001.

[2] Thomas, E.P., Seager, J.R., Viljoen, E., Potgieter, F., Rossouw, A., Tokota, B., McGranahan, G. and Kjellen, M. Household environment and health in Port Elizabeth, South Africa, Urban Environment Series Report no. 6, Stockholm Environment Institute, South African Medical Research Council and Sida, 1999.

[3] Muller, E. Quantification of the human health risks associated with kerosene use in the informal settlement of Cato Manor, Durban, Unpublished master's thesis, University of Natal, Durban, 2001.

[4] Wisner, B., Marginality and vulnerability. Applied Geography, 18(1), pp. 25-33, 1998.

[5] Kotze, A., A new concept of risk. Risk, sustainable development and disasters: Southern perspectives, ed. A. Holloway, Periperi publications, University of Cape Town, Cape Town, 1999.

[6] ISDR, Living with risk: A global review of disaster reduction initiatives, preliminary version, International Strategy for Disaster Reduction, 2002. 
[7] UNEP, Global Environment Outlook 3: Past, present and future perspectives, Earthscan Publications Ltd., London, 2002.

[8] Binedell, M.L., The whole is greater than the sum of its parts: Cumulative risk of indoor air pollution and urban vulnerability in Cato Manor, South Africa. Masters Thesis. University of Natal, Durban, 2003.

[9] Department of Social Development. State of South Africa population report, 2003. Online. http://population.pwv.gov.za/state.htm.

[10] Rakodi C., Gatabaki-Kamau, R. \& Devas, N., Poverty and political conflict in Mombasa. Environment and Urbanisation, 12(1), pp. 153-170, 2000 .

[11] Smith, A., HIV/AIDS statistics, Department of Virology, University of Natal, Durban, 2001.

[12] Amis, P., Making sense of urban poverty. Environment and Urbanisation, 7(1), pp. 145-157, 1995.

[13] Wratten, E., Conceptualising urban poverty. Environment and Urbanisation, 7(1), pp. 11-36, 1995.

[14] Moser, C., Asset vulnerability framework: Reassessing urban poverty reduction strategies. World Development, 26(1), pp. 1-19, 1998.

[15] Zawaira, F., HIV/AIDS: The unmitigated disaster, Risk, sustainable development and disasters: Southern perspectives, ed. A. Holloway, Periperi publications, University of Cape Town, 1999.

[16] WHO, Health and sustainable development: Meeting of senior officials and ministers of health, summary report, Johannesburg, 2002.

[17] Al-Khatib I., Ju'ba A., Kamal N., Hamed N., Hmeidan N. \& Massad S., Impact of housing conditions on the health of the people at al-Ama'ri refugee camp in the West Bank of Palestine. International Journal Environmental Health Research, 13(4), pp. 315-326, 2003.

[18] Law, E., Quantification of the human health risks of $\mathrm{NO}_{2}$ pollution in Johannesburg and Cape Town, CSIR Report ENV-P-I-99010, Pretoria, 1999.

[19] UN, Indicators of sustainable development: Guidelines and methodologies, United Nations, 1995. Online.

http://www.un.org.za/esa/sustdev/indisd/isdms2001/isd-ms2001isd.htm

[20] Moser, C., Urban social policy and poverty reduction. Environment and Urbanisation, 7(1), pp. 159-171, 1995.

[21] Rios R., Poje V.G. \& Detels R., Susceptibility to environmental pollutants among minorities. Toxicology and Industrial Health, 9(5), pp.797-820, 1993.

[22] Oosthuizen, R. and John, J., Trends in air quality and health, CSIR Report ENV- P- I- 2002-003, Pretoria, 2002.

[23] HST, South African health review, Health Systems Trust, 1996. Online. http://www.hst.org.za/sahr

[24] DACE, Mpumalanga State of the Environment Report, Department of Agriculture, Conservation and Environment, Mpumalanga, 2003. 